JELTL (Journal of English Language Teaching and Linguistics)

e-ISSN: 2502-6062, p-ISSN: 2503-1848

2020, Vol. 5(3)

www.jeltl.org

\title{
Construing the Challenges and Opportunities of Intercultural Language Teaching Amid Covid-19 Pandemic: English Teachers' Voices
}

\author{
Ahmad Sugianto \\ Universitas Pendidikan Indonesia \\ ahmadsugianto@upi.edu \\ Nadya Ulfah \\ Universitas Pendidikan Indonesia \\ nadyaulfah@upi.edu
}

\begin{abstract}
Due to globalization, intercultural competence becomes one of the prominent competences in English teaching. Unfortunately, the current condition, the COVID-19 pandemic happened may not lead the intercultural language teaching run as expected because it should be moved to an online setting. Through combining qualitative and quantitative research methods with questionnaires and interviews, this study aimed to unravel the teachers' competence and the challenges and opportunities of intercultural language teaching during the current situation. This study concluded that most of the teachers' intercultural competence was deemed moderate. Furthermore, some challenges found comprised the aspects of internet access and students' psychological aspect, such as attitudes toward intercultural language teaching and learning conducted in an online classroom. Meanwhile, the opportunities found comprised the aspect of language skills, attitudes, and the other supporting skill such as critical thinking development.
\end{abstract}

Keywords: COVID-19, Intercultural Language Teaching, Intercultural Competence 


\section{Ahmad Sugianto \& Nadya Ulfah}

\section{INTRODUCTION}

The necessity to integrate intercultural competence (henceforth: IC) into language teaching has registered an increase. It is because individuals are required to adapt to the current condition in which human beings should live in a globalization era that leads to any access or connection to other people around the world feasible (Gunay, 2016). Thus, English teachers are supposed not only to emphasize their instruction on developing the students' language skills but also their IC, which can make them communicate effectively is required to be taken into account (Binkley, Erstad, Herman, Raizen, Ripley, Miller-Ricci, \& Rumble, 2012; Byram, Michael, Gribkova, Bella, \& Starkey, 2002).

IC has to do with employing three essential aspects or elements. It comprises 'attitudes, knowledge, and skill' about individuals' own cultures but also other people's cultures, so effective communication can be generated (Byram, 1997; Spitzberg \& Changnon, 2009). This type of competence is required for students to assist them in dealing with issues that will even be more challenging in the future because individuals are not only required to equip themselves with adequate cognitive competence but also communicative skills involving IC is regarded essential (OECD, 2018).

Despite having been regarded as a necessary element in English learning, IC still meets challenges in English instruction practices, particularly in the EFL context. It is found that IC is not obtained much attention and thorough investigation in the English instruction practice (Atay, Kurt, Camlibel, Ersin \& Kaslioglu, 2009; Idris, 2020). Furthermore, it is considered to be even more challenging as Bickley, Rossiter, and Abbott (2014) argue, more specifically in the context of the EFL setting, that learners usually have a shared first culture and limited access to input from and the interaction with speakers of English. Such a condition leads to the students' development of their IC is hampered.

Moreover, intercultural language teaching at present becomes even more challenging. It is because the world has been undertaking the COVID-19 pandemic. The condition makes schools all over the world should be closed down for a while, included those in Indonesia. Officially, in his speech dated March 15, 2020, the president of Republic of Indonesia, Joko Widodo, asserts, "Dengan kondisi ini saatnya kita kerja dari rumah, belajar dari rumah, ibadah di rumah (due to the recent condition, it is time for us to work from home, learn from home, and pray from home)" (Minta Masyarakat Tenang, Presiden: Saatnya Bekerja, Belajar, Dan Beribadah Dari Rumah, 2020 in https://setkab.go.id/minta-masyarakat-tenangpresiden-saatnya-bekerja-belajar-dan-beribadah-dari-rumah/). Consequently, online learning becomes an alternative.

Meanwhile, a plethora of studies which discuss IC have been investigated by several researchers in the Indonesian context (Abduh \& Rosmaladewi, 2018; Adi, 2017; Aprianoto \& Haerazi, 2019; Dollah, Syarifuddin, Abduh, Amirullah, Talib, 2017; Edi, Wello, \& Dollah, 2017; Haerazi, Irwansyah, Dedi \& Azis, 2018; Idris, 2020; Idris \& Widyantoro, 2019; Luthfia, Rosidah, \& Sofian, 2019; Miftakh, 2017; Mumu, 2017; Rosyidi \& Purwati, 2018; Sabilah, 2018; Siregar, 2016; Yulianti, 2019; Zacharias, 2005); however, limited studies discussing this amid COVID-19 pandemic was found. Thus, to fill the gap of the previous related studies, it is deemed necessary to carry out a study concerning this area, i.e., challenges and opportunities encountered in intercultural language teaching, particularly 
during the COVID-19 pandemic based on the teachers' perspectives since they are the primary executor of the instruction conducted. Particularly, the followings are the proposed research questions that are intended to be discovered based on the rationale distilled above 1) To what extent is the level of English teachers' IC?; 2) What are the challenges and opportunities perceived by teachers in using online learning to facilitate intercultural language teaching amid the COVID-19 pandemic?

\section{LITERATURE REVIEW}

\subsection{Intercultural Competence (IC): What Is It?}

Due to globalization, social interactions included various cultures within the global world, become an avoidable thing. Such a condition leads to IC as the thing required to be taken into account. Therefore, the understanding of the concept of IC is crucial. Several experts propose the concepts of IC. In this regard, Bennett (2015) perceives IC as the ability through which individuals understand other people's culture as well as have deep understanding and awareness of their own culture, which is conducted through adaptation and perspective shifts. In addition, having adequate knowledge (cognitive), attitude (affective), and actions (skill) which are interdependent, inexplicable, and intertwined with one another are required to do effective intercultural interactions (Byram, Gribkova, \& Starkey, 2002; Deardorff, 2006; Lusting \& Koester, 2010; Sercu, 2005; Spitzberg \& Changnon, 2009). In addition to the experts' proposals with respect to the concept of intercultural competence above, Fantini (2009) adds one more component into the three essential components influencing IC (attitude, knowledge, and skill), that is, awareness.

Furthermore, developing IC is deemed challenging. Fantini (2009) asserts that to obtain intercultural competence requires time and processes (p. 459). Thus, individuals should necessarily have intensive intercultural interactions to practice and cultivate it. Moreover, to bear in mind, the intercultural interactions are required to be conducted thoroughly for a backwash may emerge, such as emotional force due to overprotectiveness of a particular culture (Lusting and Koester, 2010).

\section{2. Intercultural Language Teaching amid COVID-19 Pandemic}

Intercultural language teaching is considered one of the important issues for Indonesian English teachers. It is due to the nature of the condition of Indonesian classrooms, i.e., a variety of cultural and religious backgrounds exist in Indonesian classrooms (Setiawan, 2020). Therefore, understanding the concept of intercultural competence, and particularly in the Indonesian ELT context, is crucial.

However, due to the COVID-19 pandemic, all the teaching and learning practices should be carried out from home. As a result, teachers should manage to facilitate the students by employing online learning. Based on the information reported in the document of World Bank, some challenges of employing online learning system amid COVID-19 pandemic comprise the students' low attainment and difficulties during the online conducted due to their unfamiliarity with the tools used, a process conducted and poor community background, whereas feasibility to gain success with good preparation and adequate tools constitute the opportunities that can be obtained as a result of the online learning education system (Remote Learning and COVID-19, 2020). 


\section{Ahmad Sugianto \& Nadya Ulfah}

Based on the report, to make use of the online learning system effectively, some considerations should be taken into account. In this regard, the World Bank Education Global Practice in Guidance Note: Remote Learning \& COVID-19 (2020) asserts that the adequacy of digital resources, connectivity, and students' engagement in online learning is required. Meanwhile, concerning intercultural language teaching, utilizing online tools can be the alternative to facilitate it. In this regard, there are some terms proposed by some experts when online tools are employed in intercultural language teaching. For instance, they are virtual exchange, telecollaboration, e-tandem, and online intercultural exchange, and internet-mediated intercultural foreign language education (O'Dowd, 2010, 2017, 2018).

\section{RESEARCH METHODS}

The embedded design of a mixed-method was utilized in this study. It was due to some considerations, namely to get deeper data and to facilitate the researchers in answering the research questions proposed (Cohen, Manion, \& Morrison, 2000; Hamied, 2017; Morgan, 1998; Morse, 1991).

Furthermore, the subjects encompassed teachers taking Master's in the English education study program in one university in Bandung city. There were 63 questionnaires disseminated. Nevertheless, only 52 questionnaires were filled and returned. Therefore, the total subjects concerning the data gained through the questionnaire were 52 teachers. Besides, some of the teachers were interviewed. The subjects in this study were selected and determined through a purposive sampling technique. Its rationales were based on the ease of access and the subjects' cooperativeness to participate in this study. Besides, some codes were used to keep the confidentiality of the subjects' identities.

Moreover, two types of instruments were used to collect the data of this study. First, a semi-structured interview was employed. The use of this type of interview was expected to provide deeper data about the issues concerned in this study, namely the challenges and opportunities perceived by teachers in intercultural language teaching amid the COVID-19 pandemic. Second, a questionnaire was used. It was adopted from Lázár (2008). It was utilized to assess the teachers' IC. A 5 Likert-scale ranging from never, rarely, sometimes, often, and always is employed.

Table: 1 Questionnaire Matrix (Lázár, 2008)

\begin{tabular}{|c|c|c|c|}
\hline No. & $\begin{array}{l}\text { Construct (elements of } \\
\text { intercultural competence) }\end{array}$ & Sub-construct & $\begin{array}{l}\text { Number } \\
\text { of items }\end{array}$ \\
\hline \multirow[t]{6}{*}{1.} & Attitudes & Respect & 1 \\
\hline & & Tolerance of ambiguity & 2 \\
\hline & & Open-mindedness and curiosity & 2 \\
\hline & & Empathy & 1 \\
\hline & & Self-awareness & 2 \\
\hline & & $\begin{array}{l}\text { Confidence to challenge and be } \\
\text { challenged }\end{array}$ & 2 \\
\hline \multirow[t]{4}{*}{2.} & Skills & Interaction & 4 \\
\hline & & Multiperspectivity & 1 \\
\hline & & Critical thinking & 2 \\
\hline & & Problem solving and collaboration & 2 \\
\hline
\end{tabular}


Construing the Challenges and Opportunities of Intercultural Language Teaching

\begin{tabular}{lll}
\hline & Ability to grow & 3 \\
\hline $3 . \quad$ Knowledge & Knowledge about interaction & 2 \\
& Knowledge about social practices & 1 \\
& $\begin{array}{l}\text { Knowledge about the role of social and } \\
\text { political actors }\end{array}$ & 1 \\
& $\begin{array}{l}\text { Knowledge about world views and } \\
\text { beliefs systems }\end{array}$ & 1 \\
\hline
\end{tabular}

The data of this study were analyzed by using two types of approaches. The first one was the quantitative approach having to do with the data taken through a questionnaire. All the teachers' responses were scored by using the following rules: never (1), rarely (2), sometimes (3), often (4), and always (5). Descriptive statistics were used to depict the quantitative data gleaned from a questionnaire concerning the teachers' IC. The second one was the qualitative approach, i.e., the data regarding the challenges and opportunities concerning the intercultural language teaching amid COVID-19 pandemic perceived by teachers that were gained through interview. The data gained was transcribed and put into texts to be coded to answer the research questions.

\section{FINDINGS}

\subsection{Teachers' Intercultural Competence (IC)}

The information related to the teachers' IC was obtained from the questionnaires created in a Google Form disseminated online to the subjects. The followings are the detailed results.

Table: 2 Descriptive Statistics of the Three Components of IC

\begin{tabular}{llccc}
\hline No. & Description & Attitudes & Skills & Knowledge \\
\hline 1. & Mean & 78.00 & 75.18 & 80.62 \\
2. & Std. Dev. & 7.83 & 8.19 & 10.76 \\
3. & Minimum & 58.00 & 58.30 & 56.00 \\
4. & Maximum & 92.00 & 98.30 & 100.00 \\
\hline
\end{tabular}

Based on the descriptive statistics above, the categories of each score of IC can be determined by firstly calculated the ideal mean (IM) and the ideal standard mean (ISD). In this regard, the results are interpreted based on the following criteria shown in Table 3 below.

Table: 3 Guidelines for Categories Calculation

\begin{tabular}{cc} 
Interval scores & Categories \\
\hline $\mathrm{x}>\mathrm{IM}+1.5 \mathrm{ISD}$ & Very good/high \\
$\mathrm{IM}<\mathrm{x}<\mathrm{IM}+1.5 \mathrm{ISD}$ & Good/High \\
$\mathrm{IM}-1.5 \mathrm{ISD}<\mathrm{x}<\mathrm{IM}$ & Moderate \\
$\mathrm{x}<\mathrm{IM}-1.5 \mathrm{ISD}$ & Low \\
\hline
\end{tabular}




\section{Ahmad Sugianto \& Nadya Ulfah}

Based on the guidelines for categories calculation presented in Table 3 above, the categories for attitudes, skills, and knowledge are obtained. These are shown in Table 4, Table 5, and Table 6 as follows.

Table: 4 Categories for Attitudes

\begin{tabular}{cc}
\hline Interval scores & Categories \\
\hline $\mathrm{x}>83.51$ & Very good/high \\
$75<\mathrm{x}<83.51$ & Good/High \\
$66.50 \mathrm{x}<75$ & Moderate \\
$\mathrm{x}<66.50$ & Low \\
\hline Table: 5 Categories for Skills \\
\hline Interval scores & Categories \\
\hline $\mathrm{x}>88.31$ & Very good/high \\
$78.3<\mathrm{x} 88.31$ & Good/High \\
$68.30<\mathrm{x}<78.3$ & Moderate \\
$\mathrm{x}<68.30$ & Low \\
\hline Table: 6 Categories for Knowledge \\
\hline Interval scores & Categories \\
\hline $\mathrm{x}>88.95$ & Very good/high \\
$78<\mathrm{x}<88.95$ & Good/High \\
$67.05<\mathrm{x}<78$ & Moderate \\
$\mathrm{x}<67.05$ & Low \\
\hline
\end{tabular}

By taking account of the statistics presented in Table 4 above, it can be indicated that based on the assessment conducted, on average (with the mean of 78 and std. dev. of 7.83), the teachers' intercultural competence in terms of attitudes was considered high. In this regard, in more detail, it was found that 18 teachers were categorized as very high, 17 teachers were categorized as high, 13 teachers were categorized as a moderate, and four teachers were categorized as low (Appendix).

Meanwhile, concerning skills, on average (with the mean of 77.18 and std. dev. of 8.19), based on Table 5, the teachers were considered to be moderate. In detail, five teachers were included in the low category, 20 teachers were moderate, 23 teachers were in the high category, and four teachers were categorized as very high (Appendix). 
Furthermore, based on Table 6, in terms of knowledge, the teachers' IC (with the mean of 80.62 and std. dev. of 10.76) were classified into a high category. Also, in detail, five teachers were found to have low knowledge, 18 teachers were deemed moderate, 17 teachers were categorized as high, and 12 teachers were included in the very high category (Appendix).

Meanwhile, the overall IC of the teachers can be clearly seen in Table 7 as follows.

Table: 7 Descriptive Statistics of Overall IC

\begin{tabular}{llc} 
No. & Description & Statistics \\
\hline 1 & Mean & 78.59 \\
2 & Std. Dev. & 7.97 \\
3 & Minimum & 61.80 \\
4 & Maximum & 96.80 \\
\hline
\end{tabular}

Akin to the elements of intercultural aforementioned, the categories of the overall IC are calculated by using the guideline shown in Table 3 above. Table 8 below displays the results.

Table: 8 Categories of Overall IC

\begin{tabular}{ccc}
\hline No. & Interval scores & Categories \\
\hline 1 & $\mathrm{x}>88.05$ & Very good/high \\
2 & $79.3<\mathrm{x}<88.05$ & Good/High \\
3 & $70.56<\mathrm{x}<79.3$ & Moderate \\
4 & $\mathrm{x}<70.56$ & Low \\
\hline
\end{tabular}

By consulting Table 8 above, the teachers' overall IC, with a mean of 78.59 and std. Dev. of 7.97, were categorized as moderate. Moreover, in detail, eight teachers belong to the low category, 21 teachers were included moderate, 18 teachers were in the high category, and five teachers were deemed to be very high (Appendix).

\subsection{Challenges and Opportunities of Interlanguage Teaching amid COVID-19 Pandemic}

Based on the interview conducted with six teachers on May 13, 2020, it was found that due to the current condition, i.e., COVID-19, all the English teaching processes, included intercultural language teaching, were moved to the online setting. Such a condition led to some challenges and opportunities. In this regard, according to Subject F who taught at a Language Center at one of the universities in Bandung, to facilitate her students in terms of intercultural language learning, she used Youtube to introduce the contents related to cultures. However, some challenges were encountered, i.e., these were associated with the use of applications utilized. Several students were encountered to have some problems accessing the materials from the applications. Consequently, to cope with this issue, she had to download the materials from it and shared them with the students. Meanwhile, it was also reported by her that the main and most frequently used application comprise WhatsApp 


\section{Ahmad Sugianto \& Nadya Ulfah}

voice notes. The use of this application raised the students' enthusiasm. In comparison with offline classes, online learning was deemed to be more beneficial for students since all the students could get feedback directly from her during the learning process taking place. In terms of the assessment, she conducted it through some applications, such as WhatsApp, Instagram, Twitter, and Google Form. Although the institution where she taught had facilitated her during this current situation, such as providing a Website to assist her in creating an assessment for the students, yet it was perceived that it was not user-friendly for her. In more detail, she argued, "Meskipun pihak institusi sudah memberikan website khusus kepada kami (para pendidik) untuk digunakan, tapi saya masih lebih sering menggunakan Google form bila membuat soal (albeit, the institution had already provided the website to be used for us (the educators), I tended to use Google Form if I wanted to create questions for a test)." Furthermore, she pointed out that in order to make the intercultural language teaching run well, teachers were suggested to direct students to positive things by using social media and the use of Youtube as the resources that covered intercultural contents to trigger the students' curiosity.

Meanwhile, Subject M who taught in a formal institution (i.e., a vocational high school) and a non-formal educational institution (i.e., a private English course), reported some issues while she was teaching English in which intercultural contents were integrated. During this COVID-19 pandemic, she reported that intercultural teaching was undertaken and facilitated mostly in the non-formal institution. Also, the main application used to accommodate the learning process was WhatApp. However, the use of online learning, according to her, brought some barriers or challenges. For instance, due to the volatile internet connection, she had to repeat her explanation several times. Also, some students, particularly those who were from the vocational high school, were found to consider online learning as a burden, and it led to her burnout. In this regard, she asserted, "Anak-anak yang belajar di sekolah merasa terbebani dengan tugas yang diberikan. Hal demikian membuat saya merasa capai karena mereka tidak dapat memahami materi yang diajarkan (the students studying in the (formal) school felt it as a burden for them to do the tasks given. Such a condition made me tired because they did not understand the materials taught." Moreover, she reported that cheating through 'Googling' constituted another issue dealing with online learning. Besides, not ample supports from the formal institution were also reported, i.e., the only support given to facilitate the intercultural language teaching was only a textbook.

However, she mentioned that the use of online learning created some advantages to the teaching and learning process, particularly in the non-formal institution. In this regard, she stipulated that providing feedback for the students became easier. Also, in comparison with the formal education, she argued that the non-formal institution was more supportive for her in terms of facilitating intercultural language teaching, which could be indicated by the availability of adequate resources covering intercultural contents; for instance, she mentioned

Kalau di institusi non-formal, terkait dengan intercultural competence, anak-anak lebih mengenal di sana culturenya ada apa saja. Contohnya, di buku teks terdapat penjelasan terkait market day. Jadi di negara tertentu rutin terdapat market day. Contoh 
lainnya adalah terdapat teks yang membahas Problems in India (Meanwhile, in the nonformal institution, in terms of intercultural competence, the students may be more recognizable about what the cultures from other (countries). For instance, there was in fact a routine market day in a particular country. Also, it was found that the other intercultural content in a text discussing about Problems in India).

Thus, it was, according to her, a promising place for fostering the students' intercultural competence. For instance, she asserted that the students were taught to make a descriptive text related to their own culture and compare it with the condition in India. Meanwhile, in conducting the assessment, she also reported using particular assessment rubrics that were in line with the skills learned by the students. Furthermore, she revealed that to make the English teaching and learning in which intercultural content was integrated succeed, some suggestions were given; for instance, teachers were required to be more creative and to work collaboratively with students' parents. Concerning this, working collaboratively with parents constituted a sheer agency that might lead to the success of intercultural language teaching carried out. For instance, it was found that without being instructed, her students worked together with their parents to make a Greeting of 'Eid Fitr' video that was uploaded to WhatsApp.

Besides, the other suggestions, according to Subject $M$, were teachers had to be a facilitator or students' partners to support the intercultural learning process conducted by the students. Also, teachers should equip themselves with adequate intercultural competence. Moreover, adequate supporting facilities were in need of successful online learning in which intercultural competence was integrated.

Moreover, based on the interview conducted by Subject V, some findings were revealed. Subject V who taught English at a private course reported that because of the COVID-19 pandemic, the English teaching was conducted through an online classroom. In this regard, she asserted two alternative applications or platforms used in her institution, where she taught, i.e., Zoom and Skype. Nevertheless, Skype constituted the sheer application she used for it was the only account that the students own. The intercultural materials were mostly in the form of videos or pictures containing cultures from other countries. Through such resources, she then posed some questions to make the students thought critically, and she also explained some strategies used in a communication in a certain situation. Besides, she also revealed some techniques employed to facilitate the students' intercultural learning, i.e., games, crosswords, and discussions. However, she reported that the use of such an online classroom was perceived to be less effective for the dearth of internet connection. In detail, she stated, "Kurang efektifnya kadang (koneksinya) delay dari koneksi siswanya atau dari koneksi gurunya, atau ada masalah saat share a video atau share gambar (dan) film documentary (it was less effective because it (the connection) sometimes delayed, either from the students' connections or from the teachers' or there was some issues as I shared a video or pictures (and) a documentary film." Such connection trouble, according to her, was hard to be fixed. The only way to cope with it was by looking for a place in which there was adequate signals or internet networks. Also, it was found, according to her, some students sometimes could not focus during online learning.

Albeit some challenges were encountered when Subject V introduced intercultural materials through online learning, she emanated that it obtained students' positive impression 


\section{Ahmad Sugianto \& Nadya Ulfah}

and it also turned out to increase their critical thinking ability and to influence their behavior or attitude. In detail, she mentioned, "Mereka menjadi lebih kritis terhadap budaya luar itu seperti apa, kemudian bisa memilih mana yang bisa dilakukan, mana yang tidak, bagaimana cara berbicara dengan orang-orang di berbagai negara (they became more critical of other cultures, and they could decide which one could be conducted or which one was not, and how to speak with people from various countries)." Also, she reported that although it was amid COVID-19, online learning did not decrease the students' motivation to learn English. Besides, she mentioned that establishing moral values, avoiding misunderstanding, and sharpening critical thinking constituted the benefits that the students could obtain through intercultural language teaching. Furthermore, she mentioned that teachers' creativity and innovation constituted the caveats that were required to ponder by teachers to make the intercultural language teaching become successful.

The other teacher, Subject N, who taught at Language Center at one of the universities in Bandung city, revealed several encounters and emanated her perspectives on intercultural language teaching during COVID-19. In this regard, she mentioned that some challenges encountered comprised internet access. Besides, limited quota constituted the other challenges faced. Some students complained about their limited internet quota, hence to cope with some issues, she always made some notice about the materials and types of applications or platforms that would be used, so the students might have some preparations, including the internet quota. Consequently, such an online course made her and her colleagues had to exert to do some rigorous planning through generating a course timeline listing what types of materials with the platforms that would be employed so they could inform these things to the students. Also, she revealed the techniques were discussions or asking and answering questions with some students in the WhatsApp group. Moreover, insecurity related to the security system that was owned by the platforms became another issue; for instance, some students perceived to have been hacked in Zoom. Such a condition led her to decide to use other platforms, such as Google Meet or Cisco Webex.

Moreover, by having online learning, the students, based on Subject N's information, still seemed motivated to learn English, which could be indicated by the condition and enthusiasm in which most of the students always attended the class until 12 meetings, and they still cared about their own learning. For instance, if they had something to ask, they sent some messages to her (through personal chat on WhatsApp) to ask about some materials that they still had not understood yet. Besides, they could finish the tasks given in time. In regard to the intercultural task given, for instance, students were required to give a presentation about the goods from their own villages or cities.

Meanwhile, the assessment was conducted by observing the students' activity in Whatsapp group discussion and individual presentation. Moreover, Subject $\mathrm{N}$ also reported that her institution provided some supports to sustain online teaching and learning, for instance, through training, reinforcement through video conference coupled with the other teachers. Besides, to deepen and sharpen her knowledge and practical, effective teaching strategies, she sometimes attended her colleagues' online classes held in Zoom, either to give feedback on them or to learn from them. In addition, in the online classroom, teachers had some roles, such as facilitator that would not only provide time to facilitate the students' 
learning in the online classroom but also outside the classroom when they needed her/him. The other teacher's role was evaluator or controller or filter that evaluated or controlled or filtered the cultural contents that were appropriate for the students.

Moreover, the other teacher, Subject H, a male English teacher teaching in a vocational high school and junior high school levels at Pelabuhan Ratu in Sukabumi West Java, also reported some findings related to the intercultural teaching during the COVID-19 pandemic. Some challenges were found. For instance, he stated that internet access for the students was limited because most of the students lived in remote areas. Due to such a condition, he asserted that he did not give too many exposures concerning intercultural language instruction. The rationales for such actions were because more internet access was required, and it was perceived not effective if the students only learned IC through writing or reading texts. It might be better if the students might see or learn from videos, yet internet access became the barrier.

Meanwhile, according to Subject $\mathrm{H}$, the application that was most frequently used was WhatsApp, i.e., through the WhatsApp group, albeit he had ever used other types of platforms such as Google Classroom and Zoom. Nevertheless, due to the students' dearth of Information and Communication Technology (ICT) literacy and internet access, he preferred using WhatsApp, which was, according to him, friendly-user and it did not spend much internet quota. Furthermore, he also reported that most of the students felt bored to study in an online classroom amid the COVID-19 pandemic. To cope with this issue, he motivated their students by providing some reinforcement in the form of points that were given if they could accomplish some tasks. When they had already enough points, they could exchange the points with a particular reward or prize. Also, he argued that the teachers' roles comprised as a facilitator, but as he perceived that the cultural contents were too complex, he tried to dominate the teaching and learning process to direct the students. In terms of the assessment conducted, the application used mostly was Google Form. In this regard, he shared the link containing the test given, and he also provided some time (deadline, which was not too tight) to the students to finish the tasks. Some suggestions were proposed by him to make the intercultural language teaching ran as it was expected. For instance, he emphasized the teachers to be creative, not only focus on the resources from a text or video, but it could be traced from other types of resources. However, due to this COVID-19 pandemic, it seemed that in his context, it was better if he provided more explanations to the students. The explanations were required to be related to the learning themes. Also, he asserted that the need for inserting intercultural content was a must for teachers, particularly for teachers who taught at vocational high school.

Furthermore, Subject B, who worked at a vocational high school in Bandung city, reported some findings related to the intercultural language teaching conducted amid the COVID-19 pandemic. According to her, it was found that some of the students were ignorant when they were given some tasks in an online classroom. Albeit having some communication with their parents, some students were still found to have a lack of care for the assignment given. Regarding this condition, the students' classroom teacher and vice headmaster of curriculum tried to assist her in coping with the issue. Also, she revealed that internet access became the next issue for some students living in a remote area, and it led to the inefficiency of the use of the online classroom. Besides, some students perceived that due 


\section{Ahmad Sugianto \& Nadya Ulfah}

to the COVID-19 pandemic, there was not any learning, or it was considered free, albeit she had already tried to warn the students' parents that the learning was moved to the online classroom.

Nevertheless, having some challenges, online learning also provided some promising stances. In this regard, subject B reported that there were some changes in students' attitudes during online learning. Some of them had better behavior and attitudes toward teachers when sending some messages. Also, using an online platform could tighten the rapport between her students and her. She became more knowledgeable of the students' problems, for some students sometimes communicated with her directly through the WhatsApp chat. They did not hesitate to tell her about their problems. Meanwhile, the assessment was perceived the same as the regular assessment conducted when teaching in a face to face setting; namely, they were assessed through rubrics prepared but with some additional new rules. Concerning the new rules, according to her, some students would get some bonus points if they could hand over the tasks given on time and very well. The tasks were mostly disseminated through Google Classroom. Also, she suggested that in teaching intercultural language teaching, teachers were required to deliver the intercultural contents gradually or step by step through seeing their condition, whether they had been already ready to receive the contents or not. Besides, story-telling might be employed to teach intercultural content to the students; hence, the teachers are required to be a storyteller.

\section{DISCUSSION}

Concerning the findings mentioned above, the teachers' level of overall intercultural competence was deemed to be moderate. This result opposed to the findings encountered by Idris (2020), who revealed that the teachers' intercultural competence in his study were categorized as high. However, in more detail, two of the components of intercultural competence, namely attitudes and knowledge, were classified into high, yet the teachers' intercultural skill was deemed to be moderate. Therefore, it should be taken into account by teachers since intercultural competence constituted an important element in language learning and teaching, and teachers are the main actors who deliver and facilitate the students to be successful language learners and intercultural speakers (Byram et al., 2002). Besides, it became more important as globalization requires intercultural competence (Gunay, 2016).

In addition to the findings above, the challenges encountered during the online classroom in relation to IC had to do with internet access, as reported by most of the teachers. This finding was also corroborated by and in line with the findings in some studies that internet access became one of the unavoidable issues during online learning or teaching (Aboderin, 2015; Koomson, 2018), and particularly in online intercultural exchange (Ekici, 2018; Hockly, 2014). Furthermore, some teachers were found that they both felt some unclear stances whether they had to provide the students as a facilitator or the instructor who dominated the students' learning. Most of them responded to such issues with diplomatic answers that they should become both facilitators and filters/controllers who determined the students' learning. This finding was in line with what O'Dowd (2007) asserts that teachers sometimes were found to be confused about their roles whether they should put the emphasis 
on students' autonomy or as giving direct guidance to the students and hence tend to be teacher-centered.

The other problems were highlighted that the students' proficiency might become the barriers as they conducted online learning. This issue was conveyed by Subjects $\mathrm{H}$, N, and M. Such issue had to be rigorously considered since it is one of the elements that may turn out the online intercultural teaching and learning was successful (O'dowd, 2005). Moreover, it was also found that some teachers had already delivered the materials in which the intercultural content was inserted and integrated based on some major categories of tasks in virtual exchange (O'Dowd \& Waire, 2009), for instance, information exchange tasks (mentioned by most of the teachers), comparison and analysis (mentioned by subject $\mathrm{V}$ and $\mathrm{N}$ ), collaborative tasks (mentioned by subject $\mathrm{M}$ ). In addition, other issues comprise the students' ignorance, which was mentioned by subjects B and M. Meanwhile, boredom was another challenge mentioned by subject H. Such issues were also reported by White (2003), who asserts that students' continuous participation constitutes a crucial matter, and the way the students felt engaged in the learning tasks may influence the way they acquire the target language (Rogerson-Revell, 2007). Teachers are, thus, required to ensure that the students have known their roles in distance learning, i.e., the students should be responsible for their own learning (Hurd, 2006). To this end, the teachers can empower the students' peers to monitor and supervise the way each student involves in online learning that eventually brings expected and significant progress of their learning (Lan, Liu, \& Bawanwal, 2020). Moreover, the online learning system, which is friendly-user and well designed for students, should be taken into account to make the teachers' instructions take place (Costley, 2019). Adaptations of the digital tools used that suit the goals of language learning and teaching conducted, and students' needs are required and suggested (Chun, Smith, \& Kern, 2016); Subjects V, N, and $\mathrm{H}$ were found to conduct this suggestion, in this case, for instance, subject V deployed Skype with the consideration, that was, the students' familiarity with the platform indicated by all the students had the accounts; meanwhile subject $\mathrm{N}$ showed her understanding of their students' needs of security and safety during online learning was taking place by using safer platforms such Google Meet or Cisco Webex, and subject $\mathrm{H}$ utilized WhatsApp and Google Form as the learning platform since it could mitigate the students' limited internet quota.

Despite having some challenges, online teaching conducted has some benefits. For instance, it could increase the rapport between students and a teacher, which was found by subject B. Building a good rapport between student and teachers are important for it leads significantly to the students' successful performance (Nagel, Blignaut, \& Cronjé, 2009). Besides, subjects $\mathrm{N}$ and $\mathrm{F}$ also revealed that it led to the students' enthusiasm. These results follows a study carried out by Holbrey (2020), who found that the use of technology had brought positive students' engagement; similarly, Liaw and Master (2010) assert that enjoyment and authentic communication turn out students' confidence in English language competence, and the establishment of rapports amidst the students can be accommodated through online learning. However, this finding is also challenged by an assertion deriving from Panitz (2000), who explicates that the affective aspect of human beings, namely social interaction, is in danger as a result of the use of technology. A neutral voice was advocated by a study conducted by Govender (2010), revealing that students tended to benefit from 


\section{Ahmad Sugianto \& Nadya Ulfah}

mixed-mode learning system, namely face to face combined with online learning, and it eventually led to their positive motivation to the tasks given.

Moreover, enhancing critical thinking ability became the other promising stance for integrating intercultural content into English learning, particularly through online learning as reported by subject $M$. This finding is supported with a study conducted by Sinclair (2003) who found that higher-order thinking and reasoning skill were demonstrated by the students via online learning; nevertheless, this finding is in contrast with the study conducted by Chari and Haughey (2006) who encountered that faculty members still held credence to make use of face to face learning to entrench the critical thinking ability. The ability to think critically constitutes one of the essential elements in IC, and exactly it belongs to the skill element (Lázár, 2008). Therefore, it is important to foster it. However, whether the use of technology may accommodate this end, it seems it is affected to the users themselves because Panitz (2000) found that the stakeholder operating it became the crucial factor for the students or faculty to be involved in a decision making that actually can practice their criticisms toward a matter. To bear in mind, the success of distance learning course depends upon the individual supports given to the students that comprise 'feedback on performance, guidance, endeavors to develop the students' metacognitive skill, qualified teachers, and spaces to have personal dialogues (Mayes, 2001). In addition, concerning the intercultural language teaching in the online setting, teachers are required to have telecollaborative competences (O'Dowd, 2013) and familiarity with the technology used (Lee, 2009).

\section{CONCLUSION}

This study reached a conclusion that most of the teachers' IC is deemed to be still categorized as moderate. This leads some of them to meet some barriers during the intercultural language teaching carried out; hence it should be taken into account. Furthermore, some challenges comprised the aspects of internet access and students' psychological aspect, such as attitudes toward the teaching and learning conducted in an online classroom. Meanwhile, the opportunities comprised the aspect of language skills, attitudes, and other supporting skills such as critical thinking development. This study eventually advocates for future research to scrutinize the views from students and to assess the students' IC as a result of the intercultural language teaching conducted; also, classroom observations can be employed to gain an in-depth result.

\section{REFERENCES}

Abduh, A., \& Rosmaladewi, R. (2018). Promoting intercultural competence in bilingual programs in Indonesia. SAGE Open, 1 -7. https://doi.org/10.1177/2158244018788616

Aboderin, O. S. (2015). The challenges and prospects of E-learning in the National Open University of Nigeria. Journal of Education and Learning (EduLearn), 9(3), 207-216. https://doi.org/10.11591/edulearn.v9i3.1728

Adi, S. S. (2017). Increasing students' intercultural communication competence by utilizing the blended learning model. Erudio (Journal of Educational Innovation), 3(2), 25-36.

Aprianoto, \& Haerazi. (2019). Development and assessment of an interculture-based 
instrument model in the teaching of speaking skills. Universal Journal of Educational Research, 7(12), 2796-2805. https://doi.org/10.13189/ujer.2019.071230

Atay, D., Kurt, G., Ersin, P., \& Kaslioglu, Ö. (2009). The role of intercultural competence in foreign language teaching. Inonu University Journal of the Faculty of Education, 10(3), $123-135$.

Bennett, J. M. (2015). The SAGE encyclopedia of intercultural competence. SAGE Publications Ltd. https://doi.org/10.4135/9781529714395.n310

Bickley, C., Rossiter, M. J., \& Abbott, M. L. (2014). Intercultural communicative competence: beliefs and practices of adult English as a second language instructor. Alberta Journal of Educational Research, 60(1), 135-160.

Binkley, M., Erstad, O., Herman, J., Raizen, S., Ripley, M., Miller-Ricci, M., Rumble, M., \& Rumble, M. (2012). Defining twenty-first-century skills. In P. Griffin et al. (Ed.), Assessment and teaching of 21st-century skills (pp. 17-66). Springer. https://doi.org/10.1007/978-94-007-2324-5

Byram, M. (1997). Teaching and assessing intercultural communicative competence. In Issues in Coursebook Evaluation. Multilingual Matters. https://doi.org/10.1163/9789004387379_005

Byram, M., Gribkova, B., \& Starkey, H. (2002). Developing the intercultural dimension in language teaching: A practical introduction for teachers. Language Policy Division, Directorate of School, Out-of-School and Higher Education, Council of Europe.

Chari, H., \& Haughey, M. (2006). The introduction of online learning: A case study of YCMOU. Distance Education, 27(1), 87-104. https://doi.org/10.1080/01587910600653405

Chen, W. C., Shih, Y. C. D., \& Liu, G. Z. (2015). Task design and its induced learning effects in a cross-institutional blog-mediated telecollaboration. Computer Assisted Language Learning, 28(4), 285-305. https://doi.org/10.1080/09588221.2013.818557

Chun, D., Smith, B., \& Kern, R. (2016). Technology in language use, language teaching, and language learning. The Modern Language Journal, 100, 64-80. https://doi.org/10.1111/modl.12302

Cohen, L., Manion, L., \& Morrison, K. (2000). Research methods in education (Fifth). Routledge. https://doi.org/10.4324/9781315456539

Costley, J. (2019). How system functionality improves the effectiveness of collaborative learning. Interactive Learning Environments, O(0), 1-13. https://doi.org/10.1080/10494820.2019.1703009

Deardorff, D. K. (2006). Identification and assessment of intercultural competence as a student outcome of internationalization. Journal of Studies in International Education, 10(3), 241-266. https://doi.org/10.1177/1028315306287002

Dollah, Syarifuddin, Abduh, Amirullah, Talib, A. (2017). Intercultural sensitivity in the English Department. International Journal of Language Education, 1(2), 38-43.

Edi, Wello, B., \& Dollah, S. (2017). Investigating the students' strategies in developing intercultural communicative competence (ICC) model in Indonesia university context. Journal of Language Teaching and Research, 8(6), 1234-1240. https://doi.org/http://dx.doi.org/10.17507/jltr.0806.28

Ekici, D. (2018). Developing intercultural competence through online English language 
Ahmad Sugianto \& Nadya Ulfah

teaching [University of San Francisco]. https://repository.usfca.edu/diss/474

Fantini, A. E. (2009). Assessing intercultural competence: Issues and tools. In D. K. Deardoff (Ed.), The SAGE handbook of intercultural competence (pp. 456-477). SAGE Publications, Inc. https://doi.org/10.1163/ej.9789004172067.i-752.65

Govender, D. W. (2010). Attitudes of students towards the use of a Learning Management System (LMS) in a face-to-face learning mode of instruction. Africa Education Review, 7(2), 244-262. https://doi.org/10.1080/18146627.2010.515394

Guidance Note: Remote learning \& COVID-19. (2020). The World Bank Education Global Practice. http://documents.worldbank.org/curated/en/531681585957264427/GuidanceNote-on-Remote-Learning-and-COVID-19

Gunay, O. (2016). Teachers and the foundations of intercultural interaction. Springer, 62, 407-421. https://doi.org/10.1007/s11159-016-9570-9

Haerazi, Irwansyah, Dedi, J., \& Azis, Y. A. (2018). Incorporating Intercultural Competences in Developing English Materials for Writing Classes. Journal of Language Teaching and Research, 9(3), 540-547.

Hockly, N. (2014). Online intercultural exchanges. ELT Journal. https://doi.org/10.1093/elt/ccu061

Holbrey, C. E. (2020). Kahoot! Using a game-based approach to blended learning to support effective learning environments and student engagement in traditional lecture theatres. Technology, Pedagogy, and Education. https://doi.org/10.1080/1475939X.2020.1737568

Hurd, S. (2006). Towards a better understanding of the dynamic role of the distance language learner: Learner perceptions of personality, motivation, roles, and approaches. Distance Education, 27(3), 303-329. https://doi.org/10.1080/01587910600940406

Idris, M. M. (2020). Assessing intercultural competence ( IC ) of state junior high school English teachers in Yogyakarta. Indonesian Journal of Applied Linguistics, 9(3), 628636. https://doi.org/10.17509/ijal.v9i3.23213

Idris, M. M., \& Widyantoro, A. (2019). Intercultural communicative competence (ICC): What should Indonesian EFL teachers have related to ICC's elements? Journal of English Language Teaching and Linguistics, 4(1), 67-76. https://doi.org/10.21462/jeltl.v4i1.184

Kinginger, C. (2016). Mobility for Language Learning. In S. Jager, M. Kurek, \& B. O'Rourke (Eds.), New directions in telecollaborative research and practice: selected papers from the second conference on telecollaboration in higher education (pp. 1929). https://doi.org/https://doi.org/10.14705/ rpnet.2016.telecollab2016.487 (C)

Koomson, W. K. (2018). Mobile learning: Application of WhatsApp messenger as a learning tool in a university distance learning program in Ghana. Proceedings of the 15th International Conference on Cognition and Exploratory Learning in the Digital Age, CELDA 2018, Celda, 45-52.

Lan, P. S., Liu, M. C., \& Baranwal, D. (2020). Applying contracts and online communities to promote student self-regulation in English learning at the primary-school level. Interactive Learning Environments, $\quad 0(0), \quad 1-12$. https://doi.org/10.1080/10494820.2020.1789674 
Lázár, I. (Ed.). (2008). Recognizing intercultural competence: what shows that I am interculturally competent? (Issue May). The European Wergerland Centre.

Lee, L. (2009). Promoting intercultural exchanges with blogs and podcasting: a study of Spanish-American telecollaboration. Computer Assisted Language Learning, 22(5), 425-443. https://doi.org/10.1080/09588220903345184

Lee, L., \& Markey, A. (2014). A study of learners' perceptions of online intercultural exchange through Web 2.0 technologies. ReCALL, 26(3), 281-297. https://doi.org/10.1017/S0958344014000111

Lenkaitis, C. A. (2019). Technology as a mediating tool: videoconferencing, L2 learning, and learner autonomy. Computer Assisted Language Learning, 1-26. https://doi.org/10.1080/09588221.2019.1572018

Liaw, M. L., \& Master, S. B. Le. (2010). Understanding telecollaboration through an analysis of intercultural discourse. Computer Assisted Language Learning, 23(1), 2140. https://doi.org/10.1080/09588220903467301

Lusting, M. W., \& Koester, J. (2010). Intercultural competence: Interpersonal communication across cultures. Pearson Education, Inc. https://doi.org/10.1016/01471767(95)90057-8

Luthfia, A., Rosidah, R., \& Sofian, F. A. (2019). Role of Social Media in Improving Intercultural Communication Competence : A Comparative Study of European Students in Indonesia and Indonesian Students in Europe. Pertanika Journals Social Sciences \& Humanities, 26(February), 145-154.

Mayes, J. T. (2001). Quality in an e-University. Assessment and Evaluation in Higher Education, 26(5), 465-473. https://doi.org/10.1080/02602930120082032

Miftakh, F. (2017). Intercultural English teaching and learning to young learners. Proceedings of the Fifth International Seminar on English Language and Teaching (ISELT-5), 359-366.

Minta masyarakat tenang, presiden: saatnya bekerja, belajar, dan beribadah dari rumah. (2020). https://setkab.go.id/minta-masyarakat-tenang-presiden-saatnya-bekerja-belajardan-beribadah-dari-rumah/

Morgan, D. L. (1998). Practical strategies for combining qualitative and quantitative methods: applications to health research. Qualitative Health Research, 8(3), 362-376. https://doi.org/10.1177/104973239800800307

Morse, J. M. (1991). Approaches to qualitative-quantitative methodological triangulation. Nursing Research, 40(2), 120-123.

Mumu, E. L. (2017). An Exploration of Teachers' Beliefs on the Integration of Culture in Teaching English as a Foreign Language in Junior High Schools in Minahasa/Indonesia. Murdoch University.

Nagel, L., Blignaut, A. S., \& Cronjé, J. C. (2009). Read-only participants: A case for student communication in online classes. Interactive Learning Environments, 17(1), 37-51. https://doi.org/10.1080/10494820701501028

O'Dowd, R. (2005). Negotiating sociocultural and institutional contexts: The case of Spanish-American telecollaboration. Language and Intercultural Communication, 5(1), 40-56. https://doi.org/10.1080/14708470508668882

O'Dowd, R.. (2010). Online foreign language interaction: Moving from the periphery to the 
Ahmad Sugianto \& Nadya Ulfah

core of foreign language education? Language Teaching. https://doi.org/10.1017/S0261444810000194

O'Dowd, R.. (2007). Introduction. In Robert O'Dowd (Ed.), Online Intercultural Exchange (pp. 3-16). Multilingual Matters. https://doi.org/10.4324/9781315678931

O'Dowd, R.. (2013a). Telecollaborative networks in university higher education: Overcoming barriers to integration. Internet and Higher Education. https://doi.org/10.1016/j.iheduc.2013.02.001

O'Dowd, R.. (2013b). The competences of the telecollaborative teacher. Language Learning Journal. https://doi.org/10.1080/09571736.2013.853374

O'Dowd, R.. (2017). Virtual exchange and internationalizing the classroom. Training Language and Culture, 1(4), 8-24. https://doi.org/10.29366/2017tlc.1.4.1

O'Dowd, R.. (2018). From telecollaboration to virtual exchange: state-of-the-art and the role of UNICollaboration in moving forward. Journal of Virtual Exchange, 1(2018), 1-23. https://doi.org/10.14705/rpnet.2018.jve.1

O'Dowd, R., \& Waire, P. (2009). Critical issues in telecollaborative task design. Computer Assisted Language Learning, 22(2), 173-188. https://doi.org/10.1080/09588220902778369

OECD. (2018). The future of education and skills Education 2030.

Panitz, T. (2000). Will You Still Be Teaching in the Twenty-First Century? Humanistic Mathematics Network Journal, 1(23), 1-16. https://doi.org/10.5642/hmnj.200001.23.03

Remote Learning and COVID-19. (2020). http://documents.worldbank.org/curated/en/266811584657843186/Rapid-Response-

Briefing-Note-Remote-Learning-and-COVID-19-Outbreak

Rogerson-Revell, P. (2007). Directions in e-learning tools and technologies and their relevance to online distance language education. Open Learning, 22(1), 57-74. https://doi.org/10.1080/02680510601100168

Rosyidi, A., \& Purwati, O. (2018). Revealing Intercultural Communicative Competence in an EFL High School Textbook. Advances in Social Science, Education and Humanities Research (ASSEHR), 108(SoSHEC 2017), 65-69.

Sabilah, F. (2018). Intercultural competence in learning English as a foreign language in Indonesia: a pragmatic analysis. Advances in Social Science, Education and Humanities Research, 231, 414-417.

Sercu, L. (2005). Foreign language teachers and intercultural competence: an international investigation. Multilingual Matters Ltd.

Setiawan, B. N. (2020). A place for intercultural curriculum in our education reform. https://en.tempo.co/read/1293562/a-place-for-intercultural-curriculum-in-oureducation-reform

Sinclair, C. (2003). Mentoring online about mentoring: Possibilities and practice. Mentoring and Tutoring: Partnership in Learning, 11(1), 79-94. https://doi.org/10.1080/1361126032000054826

Siregar, F. L. (2016). In pursuit of intercultural communicative competence: an investigation into English language policy and practices at communication at a private university in Indonesia. Victoria University of Wellington. 
Construing the Challenges and Opportunities of Intercultural Language Teaching

Spitzberg, B. H., \& Changnon, G. (2009). Conceptualizing intercultural competence. In D.

K. Deardoff (Ed.), The SAGE Encyclopedia of Higher Education. SAGE Publications, Inc. https://doi.org/10.4135/9781529714395.n310

White, C. (2003). Language learning in distance education. Cambridge University Press.

Yulianti, V. (2019). Integrating intercultural communication competencies into foreign languages learning in the industrial revolution era 4 .0. ICSSIS 2019. https://doi.org/10.4108/eai.24-10-2019.2290566

Zacharias, N. T. (2005). Developing intercultural competence through literature. Celt, 5(1), $27-41$. 